\title{
AZ EURÓPAI NYOMOZÁSI HATÁROZAT HELYE A BÜNTETŐ IGAZSÁGÜGYI EGYÜTTMÜKÖDÉS UNIÓS RENDSZERÉBEN - ESETJOGI ELEMZÉS
}

The role of the European Investigation Order in the EU policy of judicial cooperation in criminal matters - a case law analysis

$$
\text { Szijártó István }{ }^{1} 2
$$

\begin{abstract}
Absztrakt: Jelen tanulmány a dél-dunántúli régió bíróságain és ügyészségein végzett esetjogi kutatást mutatja be, amely a Somogy, Tolna és Baranya megye ügyészségei és bíróságai által kibocsátott, illetve azokhoz beérkező európai nyomozási határozatok (a továbbiakban rövidítve: ENYH) vizsgálja. A kutatás vizsgálódási szempontjai között szerepel, hogy milyen az a tipikus büntetőeljárás, amelyben ENYH kibocsátására kerül sor: milyen bűncselekmények miatt indul, milyen hosszú, milyen nemzetközi vonatkozásokkal rendelkezik és milyen módon fejeződik be. Emellett a kutatás célja, hogy a vizsgált ügyekben kibocsátott ENYH-k tartalmát is vizsgálja: adott ügyben hány ENYH-t bocsátanak ki, milyen eljárási cselekmények elvégzését rendelik el és azok milyen eljárási célokat szolgának, a kibocsátó hatóság milyen alaki követelményeket és eljárásokat határoz meg a végrehajtó hatóság számára és az ENYH útján külföldről beszerzett bizonyíték miképpen hasznosul a büntetőeljárásban. A kutatás célja az, hogy az előbbi szempontok alapján meghatározza azon esetek körét, amelyekben az ENYH alkalmazása ideális és ezzel együtt összevesse más uniós eljárásjogi eszközökkel, amelyek a tagállamok büntető igazságügyi együttmúködésében szerepet kapnak.
\end{abstract}

1 dr. Szijártó István, Pécsi Tudományegyetem, Állam- és Jogtudományi Doktori Iskola, doktoranduszhallgató. Kutatási területe az európai büntetőjog, amelyen belül elsősorban az operatív együttmúködést megalapozó jogintézmények magyar és európai gyakorlatát vizsgálja.

A szerző további munkásságát lásd a Magyar Tudományos Művek Tárában: https://m2.mtmt.hu/api/author/10073869

2 Az Innovációs és Technológiai Minisztérium ÚNKP-21-3 kódszámú Új Nemzeti Kiválóság Programjának a Nemzeti Kutatási, Fejlesztési és Innovációs Alapból finanszírozott szakmai támogatásával készült. 
Kulcsszavak: büntető igazságügyi együttmúködés, európai büntetőjog, ENYH, esetjog

Abstract: The article presents a research conducted at the courts and prosecutor's offices of the South Transdanubia region. The research includes European Investigation Orders (from hereinafter referred to as: EIO) issued and received by the prosecutor's offices and courts of Somogy, Tolna and Baranya counties. The focus of the research includes the main characteristics of the criminal proceedings in which an EIO is issued: what crimes form the basis of them, how long their duration is, what international aspects they have and how they end. In addition, the aim of the research is to examine the content of EIOs issued in the cases involved in the research: how many EIOs are issued in a given case, what investigative measures are ordered to be performed and what procedural aims they serve, what formalities and procedures are set out by the issuing authority for the execution and how evidence obtained from abroad through the EIO is utilised in criminal proceedings. The ultimate purpose of the research is to determine, on the basis of the above criteria, the range of cases in which the application of the EIO is ideal and, at the same time, to compare it with other EU procedural instruments involved in the judicial cooperation between Member States.

Keywords: judicial cooperation in criminal matters, european criminal law, EIO, case law

\section{BEVEZETÉS}

Az európai nyomozási határozat (a továbbiakban rövidítve: ENYH) az Európai Unió tagállamai között megvalósuló büntető igazságügyi együttmúködés egyik uniós jogi eszköze. Rendszertani szempontból tehát a jogintézmény helye a büntető igazságügyi együttmúködés politikájában található. Ezen belül pedig a kölcsönös elismerés elvén alapuló eljárásjogi jellegü jogintézmények sorát gazdagítja. ${ }^{3}$

\footnotetext{
${ }^{3}$ RAMOS, 2019. 53.o. Eme jogintézmények közül a legismertebb az európai elfogatóparancs és legfrissebb a befagyasztást és elkobzást elrendelő határozat. Ld.: 2002/584/IB TANÁCSI KERETHATÁROZAT; 2018/1805/EU TANÁCSI ÉS EURÓPAI PARLAMENTI RENDELET
} 
Az ENYH egy olyan komplex jogintézmény, amelyet több nézőpontból lehet megközelíteni. A jogintézmény célja, hogy hatékonyabbá tegye a tagállamok bűnüldöző és igazságügyi hatóságainak együttműködését a büntetőeljárás nyomozási szakaszában. ${ }^{4}$ Éppen ezért a jogintézményt létrehozó irányelv a nyomozási szakban korábban alkalmazott eljárási jogsegélykérelmek változatos rendszerét egyetlen jogintézménnyel kívánja felváltani, és szintén a hatékony együttműködés garantálása érdekében érvényesíti a kölcsönös elismerés elvét. Emiatt az ENYH két szempontból vizsgálható. Egyrészről vizsgálható a kölcsönös elismerés elvének szűkebb és tágabb kontextusában, másrészről pedig vizsgálható a jogintézmény tényleges gyakorlata.

E cikkben utóbbira teszek kísérletet, ugyanis a jogintézmény gyakorlatának elemzése nagy érdeklődésre tart számot, ám annak ellenére, hogy 2010-től, azaz az ENYH-t létrehozó irányelv (a továbbiakban: ENYHirányelv) tervezetének benyújtásától kezdve számos szerző foglalkozott a jogintézménnyel, átfogó gyakorlatelemzés még kevés született. ${ }^{5}$ Ennek elsődleges oka az, hogy az Európai Unió tagállamai a jogintézményt viszonylag rövid ideje alkalmazzák. Az ENYH-t létrehozó irányelvet az Európai Parlament és a Tanács 2014 áprilisában fogadta el. Az irányelv a hatályba léptető rendelkezése alapján az EU Hivatalos Lapjában történő publikálás utáni 20. napon, azaz 2014. május 21-én lépett hatályba. ${ }^{6}$ Ezzel azonban nem vált közvetlenül alkalmazhatóvá lévén, hogy irányelvről van szó, amely a nemzeti jogba történő átültetéssel válik a tagállamok jogrendjének részévé. Az implementáció határideje 2017. május 22. volt. ${ }^{7}$ Tehát ha nem számolunk azzal a ténnyel, hogy hét tagállam csak 2018-ban implementálta az irányelvet, ${ }^{8}$ akkor is - a kézirat lezárásakor - alig több, mint három és fél év gyakorlatát lehet csak elemezni. Korábban természetesen még kevesebb lehetőség volt az ENYH gyakorlati

${ }^{4}$ MiRISAN, 2018. 219.

5 A hazai szakirodalomban egyetlen gyakorlatelemző cikk született 2020-ban, amely az ENYH kezdeti alkalmazását vizsgálta országos szinten. Ld.: FARKAS, KÁRMÁN, 2020. 216245.

6 2014/41/EU TANÁCSI ÉS EURÓPAI PARLAMENTI IRÁNYELV (a továbbiakban: 2014/41/EU) 38. cikk

7 2014/41/EU 36. cikk

8 Ausztria, Bulgária, Csehország, Luxemburg, Lengyelország, Szlovénia és Spanyolország 2018-ban implementálta az irányelvet. Közülük Luxemburg implementálta legkésőbb, méghozzá 2018. szeptember 15-én. Ld.: AZ EURÓPAI IGAZSÁGÜGYI HÁLÓZAT IGAZSÁGÜGYI KÖNYVTÁRA 
alkalmazásának tudományos igényü vizsgálatára, így nem véletlen, hogy egyelőre a jogintézmény gyakorlatáról csak a Eurojust készített nagy mintán alapuló elemzést, amit az tett lehetôvé, hogy az ügynökség a jogintézmény alkalmazásának első két és fél évében több, mint 1500 esetben segítette a tagállami büntető igazságügyi hatóságokat az ENYH útján megvalósuló operatív együttmúködésben. ${ }^{’}$

Ebben a cikkben a korábban született, elsősorban elméleti kérdésekkel foglalkozó szakirodalom kiegészítése gyanánt szeretném bemutatni az európai nyomozási határozat dél-dunántúli régióban kialakult gyakorlatát és végsősoron következtetések szeretnék levonni arra tekintettel, hogy az európai nyomozási határozatot - jellegénél fogva - milyen büntetőügyekben érdemes felhasználni. E célból röviden ismertetem az európai nyomozási határozat helyét a büntető igazságügyi együttműködés politikájában, majd bemutatom a dél-dunántúli régió ügyészségein és bíróságain végzett esetjogi kutatásomat. A cikk végén pedig gyakorlati következtetéseket vonok le a kutatás eredményeiből és ennek keretében meghatározom az ENYH és az EU tagállamai között folytatott büntető igazságügyi együttmûködés legfőbb és céljuknál fogva hasonló uniós jogi eszközei közötti viszonyt.

\section{AZ EURÓPAI NYOMOZÁSI HATÁROZAT HELYE A TAGÁLLAMOK BÜNTETŐ IGAZSÁGÜGYI EGYÜTTMÜKÖDÉSÉBEN}

Az ENYH célja az, hogy hatékonyabbá tegye az EU tagállamainak nemzetközi bűnügyi együttműködését. ${ }^{10} \mathrm{~A}$ hatékony együttmûködés ebben a kontextusban rendkívül fontos, hiszen ennek biztosítása nem más, mint a büntető igazságügyi együttmûködés fő célja. A politikát a Maastrichti Szerződés 1992-ben hozta létre a közös bel- és igazságügyi együttműködés politikájának foglalatában. ${ }^{11}$ A politika létrehozásának indokai között elsősorban a bűnözés elleni hatékony fellépés igénye említendő. Ez az igény azért keletkezett, mert az Európai Unióban az 1990-es évek elejére már több évtizede trendszerűen növekedett a transznacionális - föképp szervezett bűnözés. E tekintetben különösebb változást nem lehetett várni, hiszen az EU politikai célkitűzései között szerepelt a szabad mozgás térségének

9 Eurojust (2020). Report on Eurojust's casework in the field of the European Investigation Order

10 ZÖLD KÖNYV 2009. 2. és 3. pont; Stockholmi Program 2010. 12. o.

11 MAASTRICHTI SZERZŐDÉs 1992. VI. cím 
létrehozása. A szabad mozgás térségét az uniós polgárságon belüli szabad mozgás és tartózkodás joga, továbbá a schengeni együttmúködésnek köszönhetően a határellenőrzéseknek a tagállamok közötti belső határokon történő megszüntetése alapozzák meg. Ennek fényében a tagállamok kormány- és államfői a transznacionális - ismételten főképp szervezett bűnözést biztonsági kockázatként értékelték, amelyet uniós szinten is kezelni kell. ${ }^{12}$

Az előbbi körülmények együttállása mellett a tagállamok kormány- és államföi felismerték, hogy a többé nem hagyatkozhatnak a nemzetközi bűnügyi együttmúködés addig bevett európai rendszerére, melyet az Európa Tanács bűnügyi jogsegély-egyezményei alkottak, hanem szorosabb együttmúködést kell létrehozniuk az Európai Unión belül. ${ }^{13}$ Ugyan a Maastrichti Szerződés adta keretek között nem beszélhetünk a büntető igazságügyi együttmúködés jelentôs fejlődéséről, az Amszterdami Szerződés már új jogalapok megteremtésével, ám még a harmadik pillérben marasztalva a politikát, megújította azt. ${ }^{14} \mathrm{~A}$ politika következő fejlődési szakaszát az 1999-ben megalkotott Tamperei program adta, amely többek között célul tűzte ki a kölcsönös elismerés elvének implementálását a büntetô igazságügyi együttmúködés politikájába. ${ }^{15}$

Az Amszterdami Szerződés adta primer jogi keretek között és a Tamperei program iránymutatásai alapján a tagállamok büntető igazságügyi együttmúködése idővel több irányba kezdett fejlődni. Megkezdődött a tagállamok büntető anyagi jogának harmonizációja, ami a különösen súlyos, határon átnyúló jellegû bűncselekmények elleni fellépést szolgálta, ${ }^{16}$ és elkezdett kialakulni a kölcsönös elismerés elvén alapuló eljárásjogi eszközök rendszere, amelyek megalapozzák a tagállamok bűnüldöző és igazságügyi hatóságainak operatív együttmúködését. Az elv jelentősége abban áll, hogy túlzott mértékű büntetőjogi jogharmonizáció nélkül teszi hatékonyabbá a tagállamok büntető igazságügyi rendszereinek kooperációját, méghozzá azzal, hogy extraterritorialitást kölcsönöz a tagállamok büntető igazságügyi rendszereiben meghozott ítéleteknek és igazságügyi hatósági határozatoknak. ${ }^{17}$ Ennek azért van különösen nagy jelentősége, mert az

\footnotetext{
12 Mitsilegas, Monar, Rees, 2003. 22-27.o.

13 Mitsilegas, Monar, ReEs, 2003. 20.o.

${ }^{14}$ LABAYLE, 2016. 30-31.o.

15 FARKAS, 2011. 71.o.

16 Mitsilegas, 2016 58-60. o.

${ }^{17}$ Mitsilegas, 2016. 125. o.
} 
uniós szabad mozgás térségében a bűnözők könnyedén kikerülhetnek egy tagállam joghatósága alól azzal, hogy más tagállamba távoznak. Sőt, olyan esetek is nagy számban fordulhatnak elő, amelyekben a büncselekményt eleve több tagállamban követik el, vagy a bűncselekmény elkövetője és sértettje más-más tagállamban tartózkodnak. Ha ilyen transznacionális elemmel rendelkezik egy büntetőeljárás, akkor szükségessé válik, hogy a büntetőeljárást lefolytató hatóságok együttmúködjenek külföldi társhatóságaikkal akár azért, hogy kézre kerítsék az elkövetőt, akár azért, hogy beszerezzék a külföldön fellelhetô bizonyítékokat is.

Hogy ilyen esetekben miért van szükség egy tagállam büntető igazságügyi rendszerében meghozott igazságügyi hatósági határozat elismerésére és végrehajtására egy másik tagállamban, arra a büntetőjog szigorú territorialitása a válasz. Egy tagállam bűnüldöző hatósága nem foganatosíthat eljárási cselekményeket egy másik tagállam területén. Ehelyett fel kell kérni a másik tagállam társhatóságait a kívánt eljárási cselekmény foganatosítására (legyen az egy elfogatóparancs vagy bármely nyomozási cselekmény). A kölcsönös elismerés elve abban nyújt nóvumot a korábbi bűnügyi jogsegélyrezsimhez képest, hogy a tagállamok automatikusan végrehajtják a kölcsönös elismerés elvén alapuló egyes uniós jog által létrehozott igazságügyi hatósági határozatokat. Az automatikus végrehajtás pusztán formális ellenőrzési eljárást foglal magában, ami meggyorsítja a jogsegély teljesítését. Ezzel szemben a korábbi bűnügyi jogsegélyrendszerben nem volt biztosított az eljárási jogsegélykérelmek automatikus elismerése és végrehajtása. Ehelyett a megkeresett állam minden egyedi esetben ellenőrizte, hogy a kért eljárási cselekmény végrehajtása lehetséges-e saját jogrendszere alapján is. ${ }^{18}$ Tehát a kölcsönös elismerés elvén alapuló együttmúködés rendszere hatékony alternatívát képes kínálni mind az Európa Tanács nemzetközi egyezményeire épülő klasszikus nemzetközi bűnügyi jogsegélyrezsimre, mind pedig a korábban is említett intenzív jogharmonizációra, ami ugyan alapjogi szempontból sokkal kívánatosabb volna, ám a tagállamok még jelenleg is elutasítják ezt az opciót, mivel a büntetőjog mélyen az állami szuverenitásban gyökerezik. ${ }^{19}$

A Tamperei programot követően a Tanács jogalkotó tevékenységének, továbbá a Lisszaboni Szerződés hatályba lépését követően a Tanács és az Európai Parlament társjogalkotó tevékenységének köszön-

\footnotetext{
18 KLIMEK, 2017. 9.o.

${ }^{19}$ FARKAS, 2011. 64.o.
} 
hetően mára a kölcsönös elismerés elve a büntetőeljárás egészében, és azon túlnyúlva a büntetés-végrehajtás során, valamint a vagyonvisszaszerzési eljárásban is érvényesül. ${ }^{20} \mathrm{Az}$ európai nyomozási határozat egy lépés volt eme teljesség felé, ugyanis kiterjesztette az elv alkalmazását a nyomozás szakaszára. Az Európai Unióban hosszú ideje fennálló törekvés volt, hogy egy egységes jogintézmény váltsa fel a nyomozás során alkalmazandó klasszikus nemzetközi jogsegély intézményét. ${ }^{21} \mathrm{Az}$ ENYH éppen emiatt ún. horizontális hatállyal rendelkezik, tehát kiterjed minden nyomozási cselekményre, ám emellé kelló garanciákat nyújt, amelyek megakadályozzák, hogy egyfajta fordított forum-shopping-ként a kibocsátó hatóságok visszaélésszerúen használják azt. ${ }^{22} \mathrm{Az}$ igazságügyi hatósági határozatot az ügyben eljárni jogosult ügyészség vagy bíróság bocsáthatja ki, továbbá az eljáró nyomozó hatóság, feltéve, hogy a kért nyomozási cselekmény elrendelésére saját hatáskörében jogosult és az ügyben hatáskörrel és illetékességgel rendelkező ügyészség vagy bíróság jóváhagyja a kibocsátást. ${ }^{23}$

\section{ESETJOGI KUTATÁS A DÉL-DUNÁNTÚLI RÉGIÓBAN}

\subsection{Kutatásmódszertan}

Az európai nyomozási határozattal kapcsolatos esetjogi kutatást Somogy megye, Tolna megye és Baranya megye bíróságain és ügyészségein végeztem. A kutatás tárgyát olyan büntetőügyek képezik, amelyekben európai nyomozási határozat került kibocsátására. Ennek okán a vizsgált büntetőeljárások túlnyomó többsége 2017 májusa után kezdődött, vagyis

\footnotetext{
${ }^{20}$ SZIJÁRTÓ, 2020. 74-75.o.

${ }^{21}$ Az irányelv alkalmazása felváltja az Európa Tanácsnak a kölcsönös bűnügyi jogsegélyről szóló 1959. évi európai egyezményét, annak két kiegészítő jegyzőkönyvét, és az egyezmény alapján kötött kétoldalú megállapodásokat. Továbbá felváltja a Schengeni Megállapodás végrehajtásáról szóló egyezmény megfelelő rendelkezéseit, és az Európai Unió tagállamai közötti kölcsönös bűnügyi jogsegélyről szóló egyezményt és annak jegyzőkönyveit is. Végül, de nem utolsó sorban felváltja az európai bizonyításfelvételi parancsot létrehozó kerethatározatot és a 2003/577/IB kerethatározatot - utóbbit csak részben, méghozzá a bizonyítékok biztosítására szolgáló ideiglenes intézkedéseket elrendelő határozatok tekintetében. Ld. 2014/41/EU 34. cikk (1) és (2) bekezdés

22 Azzal kerüli el az irányelv ezt, hogy az ENYH-ban csak olyan nyomozási cselekmény elvégzését kérheti a kibocsátó állam, amely hasonló belföldi ügyben is elrendelhető lenne. Ld: ARMADA, 2015. 18.o.
}

23 MONTERO, 2017. 46. o. 
miután Magyarország implementálta az ENYH-irányelvet. Az összesen 41 ügyet feldolgozó aktakutatás nem csupán azon hazai büntetőeljárásokra terjed ki, amelyekben a magyar hatóságok bocsátottak ki ENYH-t, hanem olyan ügyekre is, amelyekben a magyar hatóságokhoz külföldi kibocsátó hatóságtól érkezett megkeresés ENYH formájában.

Az aktakutatás elsősorban a kibocsátott európai nyomozási határozatokra koncentrált, ám az akták egészét vizsgáltam a nyomozási szakasztól kezdve a bírósági szakot lezáró jogerős ítéletig (amennyiben a vizsgált büntetőeljárás ekképp zárult). Az akták teljeskörű vizsgálatát indokolta, hogy nem csupán az ENYH tartalmát vizsgáltam, hanem egyéb, tartalmi szempontból járulékos, ám gyakorlati szempontból kevésbé elhanyagolható kérdéseket is, mint például azt, hogy mely hatóság kezdeményezte a kibocsátást, továbbá, hogy az ENYH útján beszerzett bizonyítékot végül felhasználták-e a büntetőeljárásban. A kutatás következetességének érdekében előre meghatározott szempontok érvényesítésével vizsgáltam az ügyeket, melyek között szerepel az előbbieknek megfelelően a büntetőeljárás tárgyát képező cselekmény minősítése, a büntetőeljárás időtartama, a kibocsátást kezdeményező hatóság, az ügy befejezésének módja, , az ENYH kibocsátására okot adó nemzetközi elem, a megkeresett tagállam, továbbá az, hogy az ügyben hány ENYH-t bocsátottak ki, milyen eljárási cselekmények elvégzését rendelték el és ez milyen büntetőeljárási célokat szolgált, továbbá, hogy a kibocsátó hatóság meghatározott-e olyan alaki követelményeket és eljárásokat, melyeket a végrehajtó hatóságnak tiszteletben kell tartania az eljárási cselekmény foganatosítása során, és végül azt is, hogy a kibocsátó hatóság végrehajtottae az ENYH-t, azaz végsősoron sikeresnek mondható-e az ENYH kibocsátása az ügyben.

\subsection{A vizsgált ügyek legfőbb paraméterei}

A kutatásba bevont 41 büntetőeljárás közül 23 ügy folyt a magyar hatóságok előtt. Ennél fogva magyar hatóság eme 23 ügyben bocsátott ki ENYH-t. A fennmaradó 18 eljárás azért indult, mert tagállami megkeresés érkezett ENYH formájában a vizsgálatba bevont valamely ügyészségre vagy bíróságra. A más tagállamokból érkező ENYH végrehajtása érdekében eljáró bíróságok büntető nemperes (Bpk.) vagy egyéb (vegyes) ügyeket 
(Beü.) indítottak. ${ }^{24}$ Ezzel szemben az ügyészség nem alkalmaz ilyen fajta iratkezelési megkülönböztetést.

A magyar hatóságok előtt folyó 23 ügyben a tettesek 14 különböző bűncselekményt követtek el. Mivel eme 23 eljárás közül egy büntetőeljárás kettő bűncselekmény elkövetése miatt indult, ezért a vizsgált ügyekben összesen 25 bủncselekményt követtek el. A magyar hatóságokhoz érkező ENYH-kat szintén 14 különböző bűncselekmény miatt bocsátották ki. Noha e 14 bűncselekmény mutat átfedést az előbbi 14 bűncselekménnyel, a lista nem egyezik teljes mértékben. Megjegyzendő továbbá, hogy a vizsgálat alá vont 18 eljárásban összesen 24 bűncselekményt követtek el azzal, hogy négy ügy kettő, egy ügy pedig három bűncselekmény miatt kezdődött. Az ENYH-val érintett bűncselekmények táblázatos összefoglalója alább látható.

\begin{tabular}{|c|c|}
\hline \multicolumn{2}{|c|}{$\begin{array}{c}\text { A magyar hatóságok előtt lefolytatott büntetőeljárások tárgyát képező } \\
\text { büncselekmények }\end{array}$} \\
\hline Büncselekmény & Bűncselekmények száma \\
\hline Csalás & 2 \\
\hline Egyedi azonosító jellel visszaélés & 1 \\
\hline Embercsempészés & 1 \\
\hline Járművezetés ittas állapotban & 6 \\
\hline Kábítószer birtoklása & 1 \\
\hline Kiskorú veszélyeztetése & 1 \\
\hline Költségvetési csalás & 1 \\
\hline $\begin{array}{l}\text { Közlekedés biztonsága elleni } \\
\text { büncselekmény }\end{array}$ & 1 \\
\hline Közokirat-hamisítás & 2 \\
\hline Lopás & 3 \\
\hline Sikkasztás & 2 \\
\hline Számvitel rendjének megsértése & 1 \\
\hline Testi sértés & 1 \\
\hline Zaklatás & 1 \\
\hline
\end{tabular}

1. sz. táblázat. Forrás: saját szerkesztés

24 17/2014. (XII. 23.) OBH utasítás 77. \(1) bekezdés a) pont 5. és 20. alpontok 


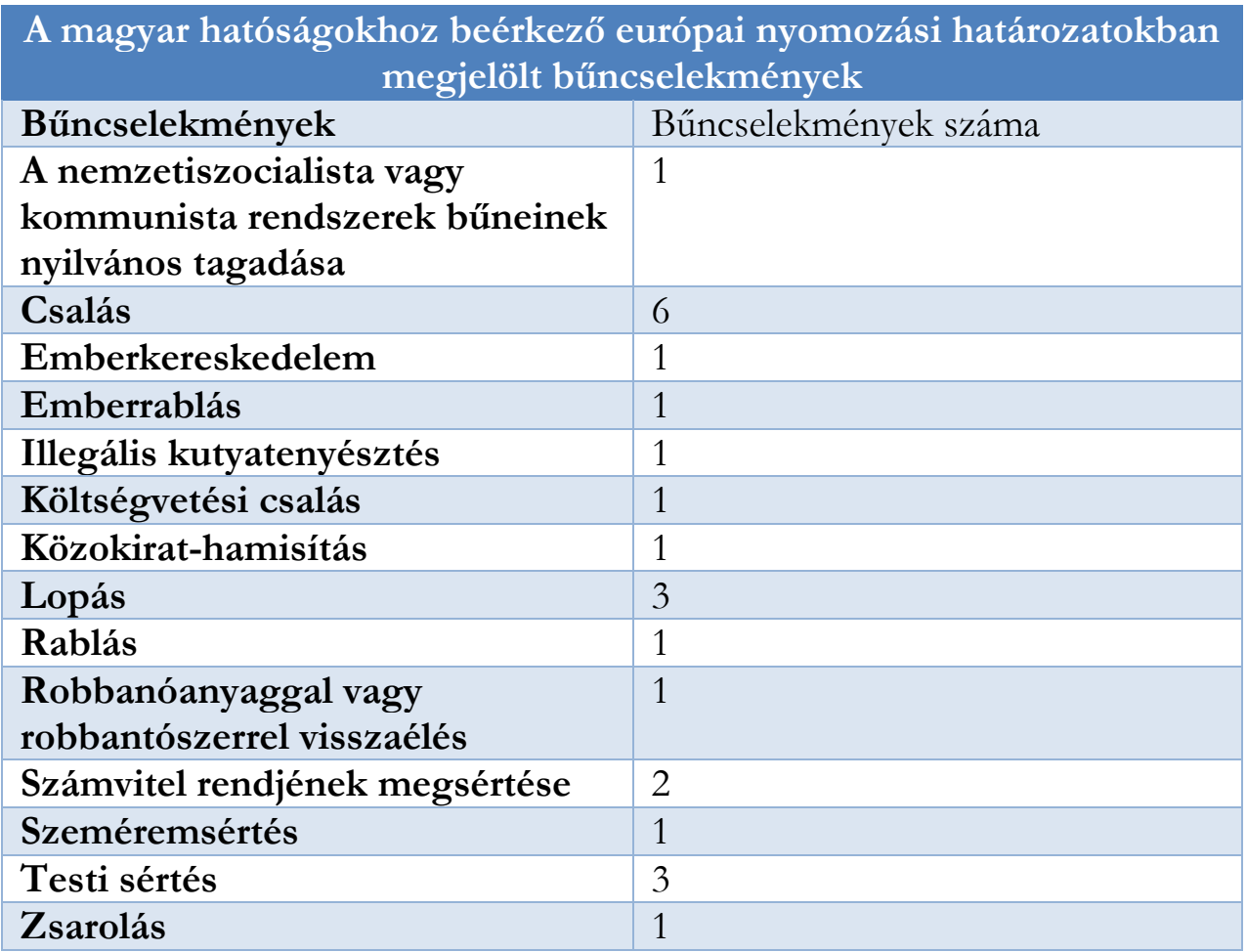

2. sz. táblázat. Forrás: saját szerkesztés

Emellett érdemes megfigyelni azt, hogy a magyar hatóságok túlnyomórészt közlekedési bűncselekmények, továbbá vagyon elleni bűncselekmények miatt bocsátottak ki európai nyomozási határozatot, míg a magyar hatóságokhoz beérkező ENYH-k abszolút többsége vagyon elleni (erőszakos) bűncselekmények miatt került kibocsátásra. ${ }^{25} \mathrm{Az}$ alábbi két szemléltető ábrával kapcsolatban megjegyzendő, hogy azon büntetőeljárásokat, melyekben a tettesek több bűncselekményt követtek el, csak egy bűncselekményhez számoltam, mivel a legtöbb eljárásban egyetlen ENYH kibocsátásra került sor még akkor is, ha több bűncselekmény miatt indult az. Emiatt a százalékos adatok nem fognak megegyezni az előbbi táblázatok alapján kiszámolhatókkal, ám csak így kerülhető el, hogy a részarányok kiszámítása torzított képet adjon arról, hogy mely bűncselekmények miatt

25 Előbbi egyértelműen Somogy megyei sajátosság, ugyanis Somogy megyei ügyészségek bocsátották ki a legtöbb ENYH-t. Somogy megyében pedig az ügyek között főleg a nyári szezonban felülreprezentáltak a közlekedési bűncselekmények a balatoni régióban. 
Az európai nyomozási határozat helye a büntető igazságügyi együttműködés uniós rendszerében - esetjogi elemzés

bocsátottak ki ENYH-t a legtöbbször. Amikor egy ENYH alapjául több bűncselekményt is megjelöltek, a legsúlyosabban büntetendő bűncselekményt tüntettem fel az ábrákon.

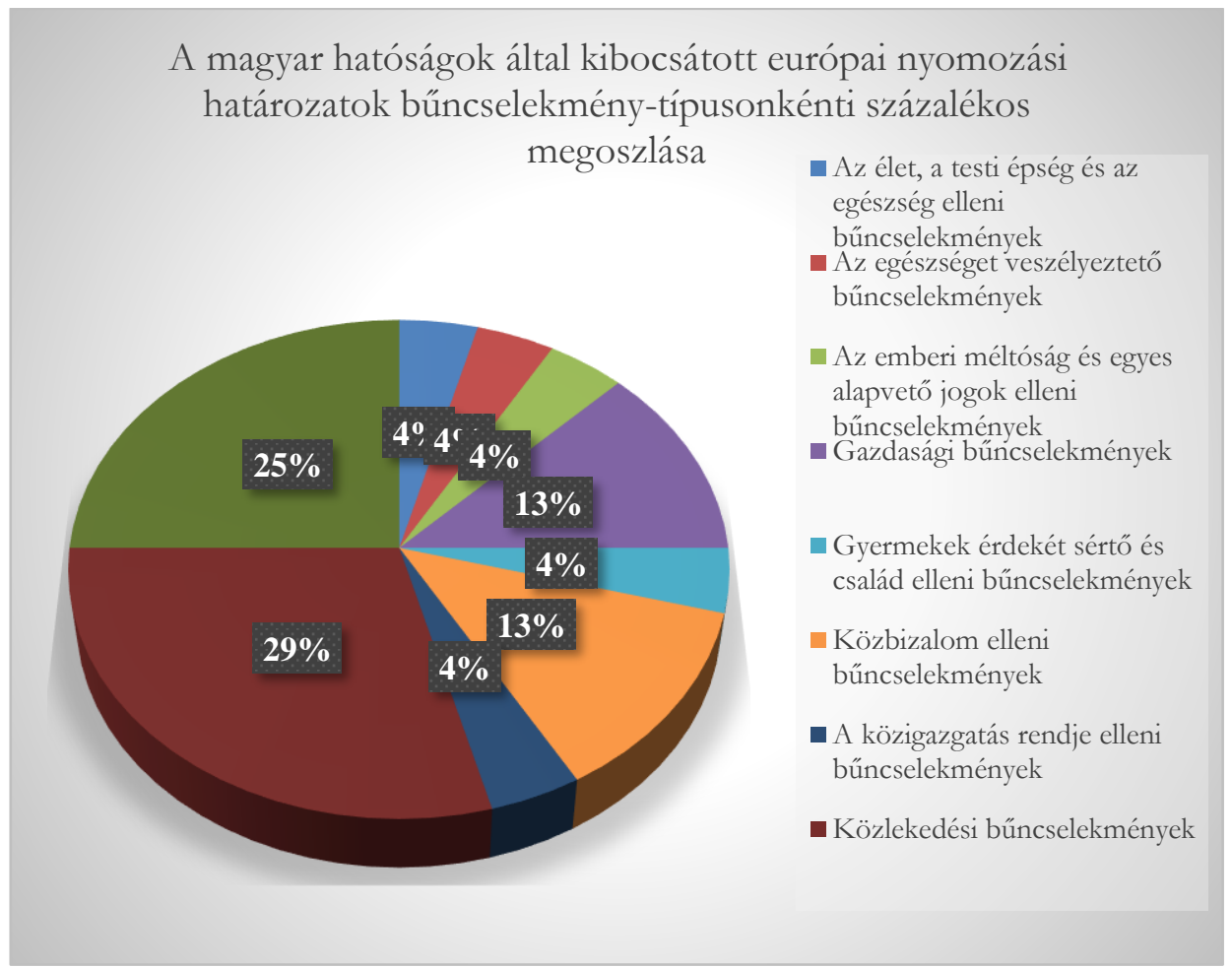

1. sz. ábra. Forrás: saját szerkesztés. 


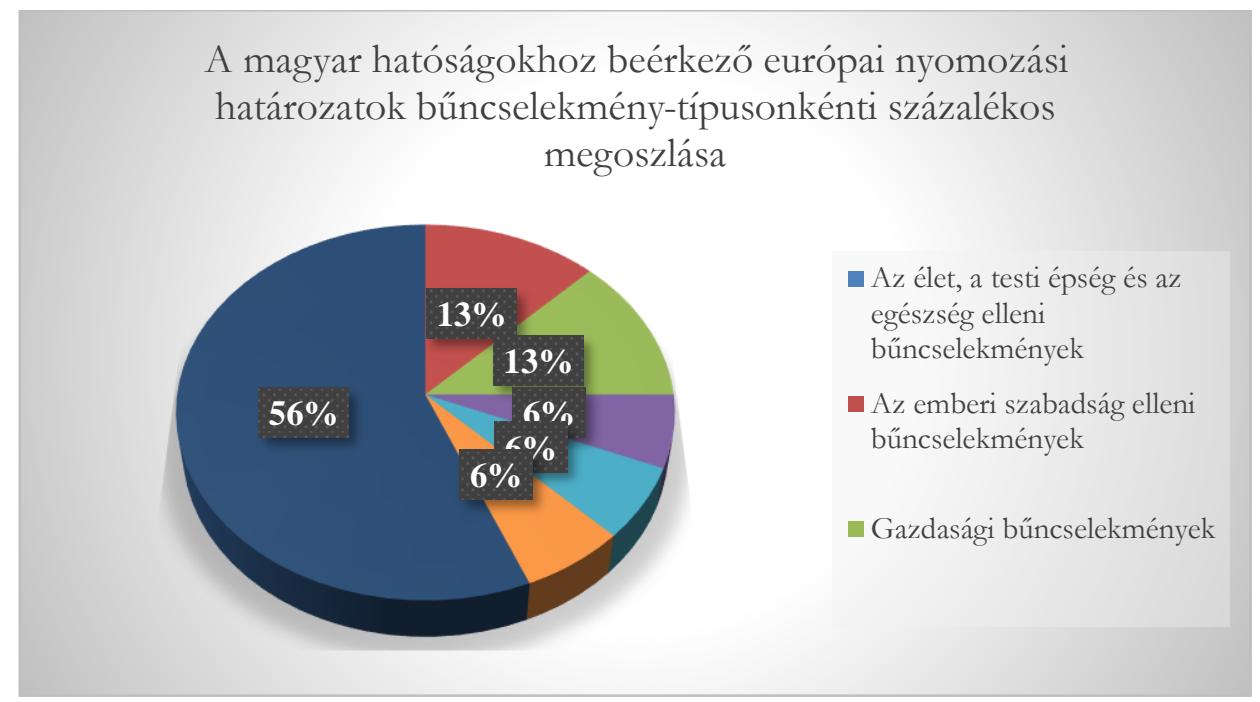

2. sz. ábra. Forrás: saját szerkesztés.

A kutatásba bevont ügyek időtartamát kizárólag a magyar büntetőeljárások tekintetében vizsgálhattam, mivel a külföldről érkező megkeresések nem tartalmaznak azok hosszára vonatkozó információkat. Emiatt a 23 magyar büntetőügyről állapítható meg, hogy azok átlagosan két évig tartottak, ám a legrövidebb időtartamú ügy 5 hónapig, míg a leghosszabb időtartamú ügy 5 év és 6 hónapig tartott. Az ügyek befejezésének módját szintén csak a magyar büntetőeljárások vonatkozásában tudtam vizsgálni, hiszen a külföldi megkeresések teljesítése után a kibocsátó hatóság nem oszt meg további részleteket a végrehajtó hatósággal sem az ENYH végrehajtása során, sem az után. Az eljáró hatóságok 9 esetben megszüntették a büntetőeljárást, mert a beszerzett bizonyítékok alapján nem nyert bizonyosságot az, hogy a bủncselekményt a terhelt követte el. Látható a 3. ábrán, hogy ezáltal a vizsgált esetek számottevő része úgy zárult, hogy nem lehetett döntést hozni a büntetőjogi felelősség kérdésében. Ezzel szemben az ügyészség 1 esetben feltételes ügyészi felfüggesztést, 5 esetben megrovást alkalmazott és az ügyészség indítványára a bíróság négy esetben büntetôvégzést hozott, melyet a terheltek nem vitattak. Ezen túl 3 esetben büntetőjogi felelősséget megállapító bírósági ítélet született, amely első fokon jogerőre emelkedett. Azaz összességében az ügyek 61\%-ban sor került a büntetőjogi felelősség megállapítására. 
Az európai nyomozási határozat helye a büntető igazságügyi együttműködés uniós rendszerében - esetjogi elemzés

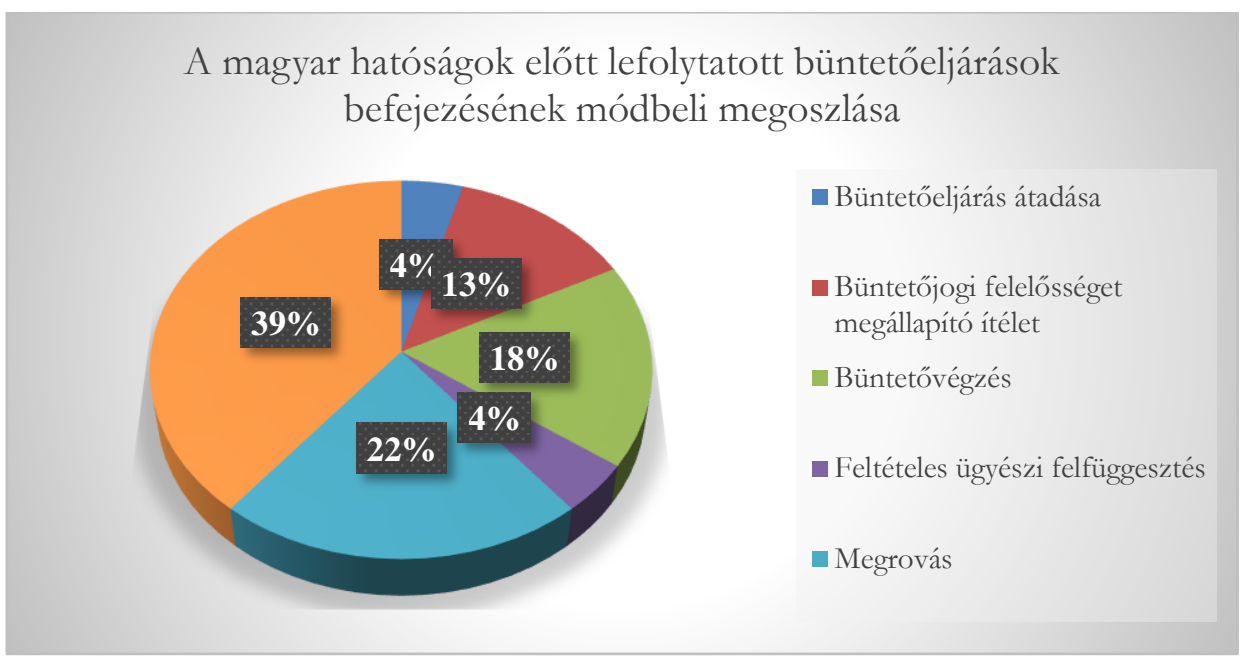

3. sz. ábra. Forrás: saját szerkesztés.

Végül van még egy szempont, ami csak a magyar büntetőeljárások vonatkozásában vizsgálható, méghozzá az, hogy mely hatóság kezdeményezésére került kibocsátásra az ENYH. A vizsgált büntetőügyekben három lehetőség merült fel: az ügyészség az ügyben hatáskörrel és illetékességgel rendelkező nyomozó hatóság kezdeményezésére, vagy saját mérlegelési jogkörében bocsátotta ki azt, vagy az ügyben eljáró bíróság saját jogkörében bocsátotta ki azt. Az esetek túlnyomó részében az ügyészség a nyomozó hatóság kezdeményezésére bocsátotta ki az ENYH-t, ám két esetben az ügyiratok nem utalnak arra, hogy a nyomozó hatóság kezdeményezte volna a kibocsátást, ezért úgy vélem, hogy ezekben az ügyészség saját kezdeményezésre bocsátotta ki az ENYH-t. Ezzel szemben csak egyetlen ügy volt, amelyben az eljáró bíróság bocsátotta ki az ENYH-t, ráadásul a bírósági szakban, ami ugyan lehetséges, ám ritka a gyakorlatban. Olyankor kerülhet rá sor, amikor a bírósági szakban bizonyítási eljárást kell lefolytatni (pl. a tanúvallomást nem annak ismertetése útján teszik az ügyiratok részévé, hanem a tanúk újból vallomást tesznek).

A gyakorlat érdekes vonatkozásaira mutathat rá még az, hogy ugyan két esetben, de előfordult olyan is a vizsgált ügyekben, amikor az ENYH kibocsátását kezdeményezte a nyomozó hatóság, ám az ügyészség elutasította azt. Az egyik esetben az ügyészség azzal indokolta eme döntését, hogy a tényállás kellően tisztázott és a beszerzett bizonyítékok alapján érdemben elbírálható az ügy, míg egy másik esetben azért nem került sor 
végül az ENYH kibocsátására, mert a telefonszámhoz tartozó előfizetői adatokat a megkeresett tagállam vonatkozó jogszabályai értelmében a szolgáltatók csak egy évig kötelesek megőrizni, ezért az ENYH kibocsátása nem lett volna alkalmas a nyomozási cél beteljesítésére.

\subsection{A büntetőeljárások nemzetközi vonatkozásai}

A magyar hatóságok a német társhatóságokat keresték meg ENYHval legtöbbször (9 ügyben), de emellett a magyar ügyekben kibocsátott ENYH-k végrehajtó tagállamai között találjuk Ausztriát (3 ügyben), Romániát (2 ügyben), Szlovákiát, Csehországot, Spanyolországos, Olaszországot, Nagy-Britanniát és Svédországot is (1-1 ügyben). A kutatás tárgyát képező 23 magyar büntetőeljárás közül csupán egyben kellett több tagállamba küldeni ENYH-t, melyet az indokolt, hogy a terhelt nem volt fellelhető az állampolgársága szerinti tagállamban, ezért az akkori tartózkodási helye szerinti tagállamot is meg kellett keresni a kihallgatás foganatosítása érdekében. A magyar hatóságokat ezzel szemben Ausztria kereste meg a legtöbbször (6 ügyben), amelyet Németország követ (5 ügyben). Ezen túl érkezett ENYH a magyar hatóságokhoz Hollandiából (4 ügyben), Horvátországból (2 ügyben) és Bulgáriából (1 ügyben). A magyar hatóságokhoz beérkező ENYH-k közül egy esetben a kibocsátó hatóság egy kiegészitő ENYH-t is kibocsátott egy további eljárási cselekmény elvégzése céljából.

A következő vizsgálódási szempont az, hogy mi indokolta az ENYH kibocsátását. A kutatást megelőző pontokban általános megállapításként már olvasható volt, hogy ENYH kibocsátására akkor kerül sor, amikor más tagállamban kell nyomozási cselekményeket elvégezni abból a célból, hogy az ügyben eljáró hatóság a külföldön fellelhető bizonyítékot beszerezze. Azokat a körülményeket, melyek szükségessé teszik ezt, nemzetközi vagy határon átnyúló elemnek nevezhetjük összefoglaló néven, és ezek teszik a szóban forgó büntetőügyeket transznacionálissá. A vizsgált ügyekben a leggyakoribb nemzetközi elem az elkövető külföldi tartózkodási helye volt (18 ügyben). Ezen túl a vizsgált büntetőügyekben nemzetközi elemként jelentkezett még a tanúk külföldi tartózkodási helye (1 ügyben), a külföldi banknál vezetett bankszámla (2 ügyben), külföldi szervezet által kiállított közokirat (1 ügyben) és a külföldön beszerzett áru magyarországi értékesítése (1 ügyben). A magyar hatóságokhoz érkező ENYH-k esetében nemzetközi elemként leggyakoribb szintén a külföldön tartózkodó terhelt 
jelent meg (12 ügyben). Ezúttal a büntetőeljárást folytató tagállamhoz képest a Magyarországon tartózkodó terhelt számít külföldön tartózkodó terheltnek. Emellett szintén megjelenik a külföldön tartózkodó tanú (3 ügyben) és a külföldi banknál vezetett bankszámla (1 ügyben). Továbbá a magyar ügyeknél nem tapasztalt nemzetközi elem volt a Magyarországon lefolytatott büntetőeljárás ügyiratainak beszerzése (2 ügyben).

A magyar hatóságok által kibocsátott európai nyomozási határozatokban megjelölt nemzetközi elemek

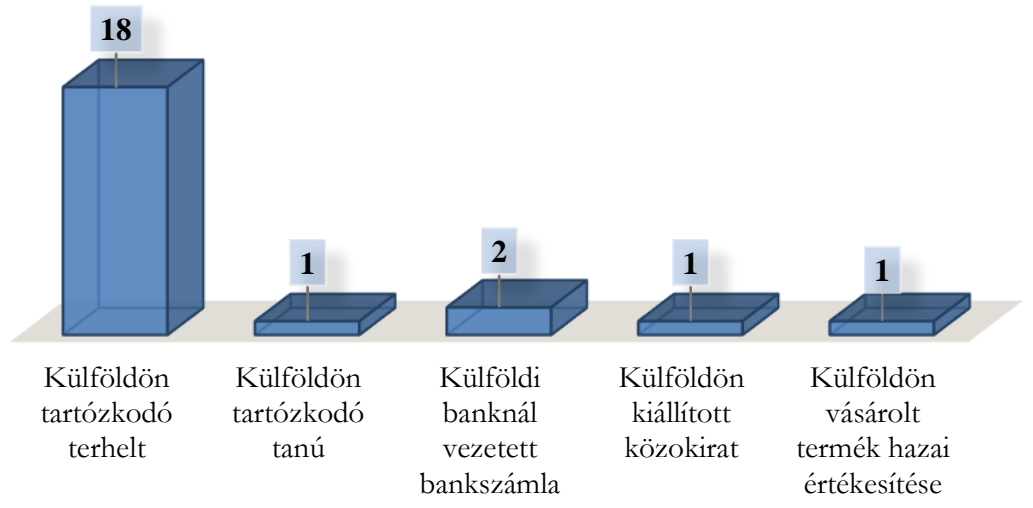

4. sz. ábra. Forrás: saját szerkesztés 
A magyar hatóságokhoz beékrező európai nyomozási

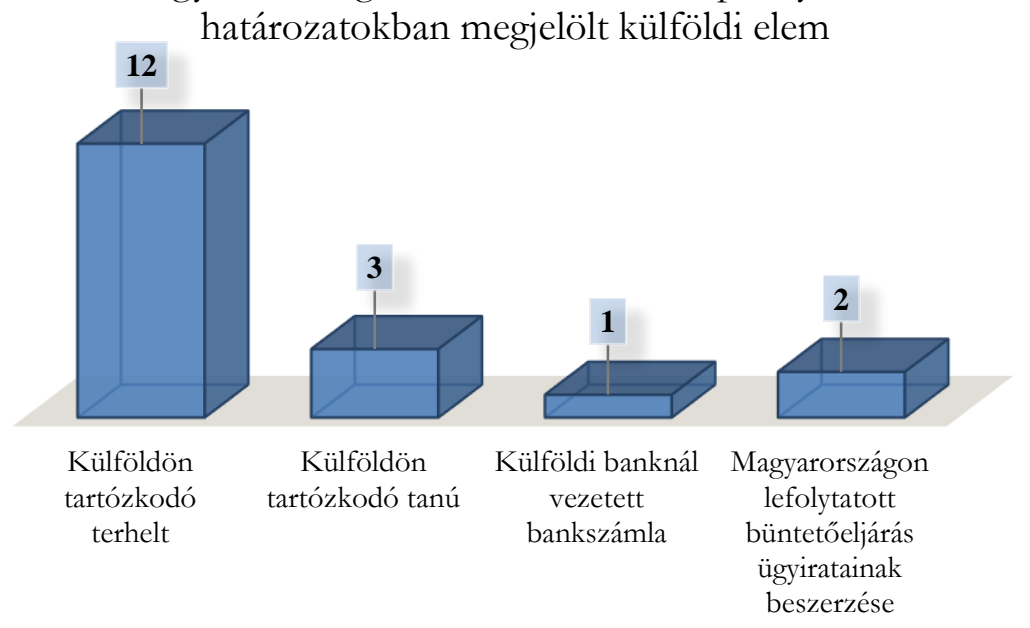

5. sz. ábra. Forrás: saját szerkesztés

\subsection{A vizsgálat alá vont európai nyomozási határozatok tartalma}

A büntetőeljárásban fellelhető nemzetközi elem már nagyban predesztinálja azt, hogy a kibocsátó hatóság milyen eljárási cselekmény elvégzését rendeli el ENYH útján és a kibocsátása milyen eljárási célokat szolgál. Ennek megfelelően, amikor a bűnügy nemzetközi vonatkozását a terhelt vagy a tanú külföldön tartózkodása adja, akkor az ENYH útján leggyakrabban kérelmezett eljárási cselekmény a terhelt gyanúsítottként történő kihallgatása. A magyar hatóságok előtt lefolytatott ügyek közül összesen 19 esetben ezek adták az ügyek nemzetközi vonását. Közülük 16 esetben rendelte el a magyar hatóság a terhelt gyanúsítását, illetve egy esetben a külföldön tartózkodó tanú kihallgatását. Továbbá, ha egy ügynek az a nemzetközi vonatkozása, hogy akár az elkövető, akár a sértett egy külföldi banknál vezetett bankszámlára utal pénzt, a nyomozás egyik célja annak kiderítése, hogy ki a bankszámla tulajdonosa. A vizsgált büntetőeljárások közül két esetben állt fenn ez a körülmény, és a magyar hatóság mindkét esetben abból a célból bocsátott ki ENYH-t, hogy a számlán végbement pénzforgalmi adatokat beszerezze, illetve a bankszámla tulajdonosának személyazonosságát megállapítsa. Egy további ügyben egy külföldi szervezet által kiállított okirat valódiságát kellett ellenőrizni. Az ENYH kibocsátásának célja annak megállapítása volt, hogy valóban a 
szervezet bocsátotta-e ki az okiratot. A kibocsátó hatóság e célból adatgyüjtést rendelt el az ENYH-ban. Végül a gazdasági bűncselekmények esetén a bekövetkezett gazdasági események bizonyítása a cél, illetve a fiktív ügyletek leleplezése. A nemzetközi elemmel is rendelkező gazdasági bűncselekményeket általában az ÁFA megfizetésének elmulasztásával követik el. Az ily módon megvalósított költségvetési csalás a hozzáadottérték adó uniós szabályozása miatt jellemző, ugyanis az importált áru után a forrás országban megfizetett HÉA visszaigényelhető, és ezt követően az elkövetőknek annyi a dolguk, hogy a célországban elleplezzék az áru eredetét vagy azt, hogy ÁFA alanyok és ezzel elkerüljék, hogy ÁFA befizetési kötelezettségük keletkezzen. A vizsgált ügyek közül egy esetben fordult elő az eme módszerrel elkövetett költségvetési csalás. A kibocsátó hatóság ebben az ügyben az import áru megvásárlását tanúsító bizonylatok lefoglalását rendelte el egyebek mellett. A magyar hatóságokhoz érkező ENYH-kban elrendelt nyomozási cselekmények szinte teljes mértékben megegyeznek az előbbiekkel és megoszlásuk is nagyon hasonló, viszont egy esetben a kibocsátó hatóság a gyanúsított kihallgatása mellett felismerésre bemutatást is elrendelt, és további két esetben nyomozási cselekmények elrendelése helyett a végrehajtó hatóság előtt lefolytatott büntetőeljárás iratainak megküldését kérte. Ez utóbbira olyankor szokott sor kerülni, amikor a büntetéskiszabás körében figyelembe kell venni, hogy a terhelt már volt büntetve, vagy egy másik tagállamban ugyanazon bủncselekmény miatt folyik eljárás, és a ne bis in idem elv értelmében meg kell szüntetni azt. A vizsgált európai nyomozási határozatokban elrendelt nyomozási cselekmények összefoglaló adatai az alábbi ábrákon láthatók. 
A magyar hatóság által kibocsátott európai nyomozási határozatban elrendelt nyomozási cselekmények

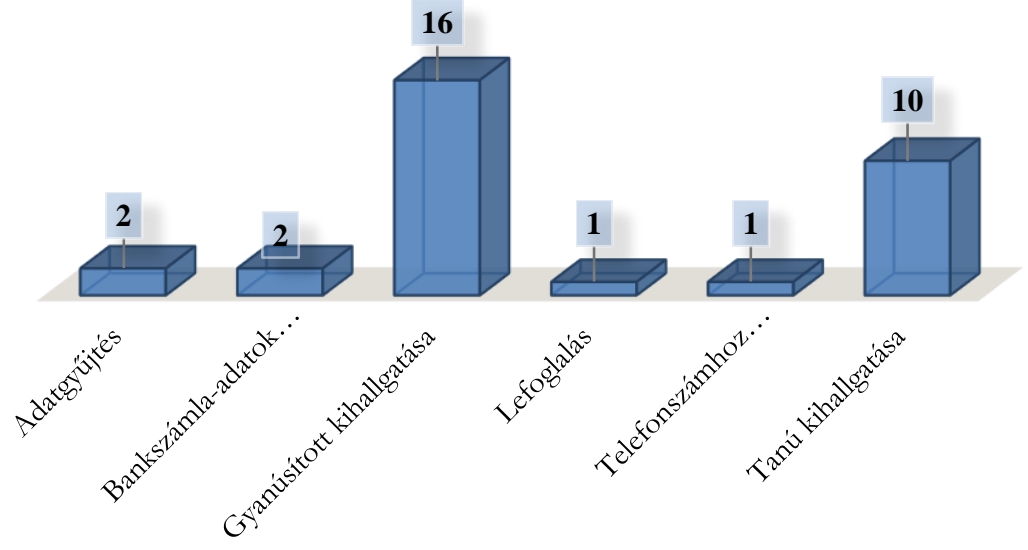

6. sz. ábra. Forrás: saját szerkesztés.

A magyar hatóság által kibocsátott európai nyomozási határozatban elrendelt nyomozási cselekmények

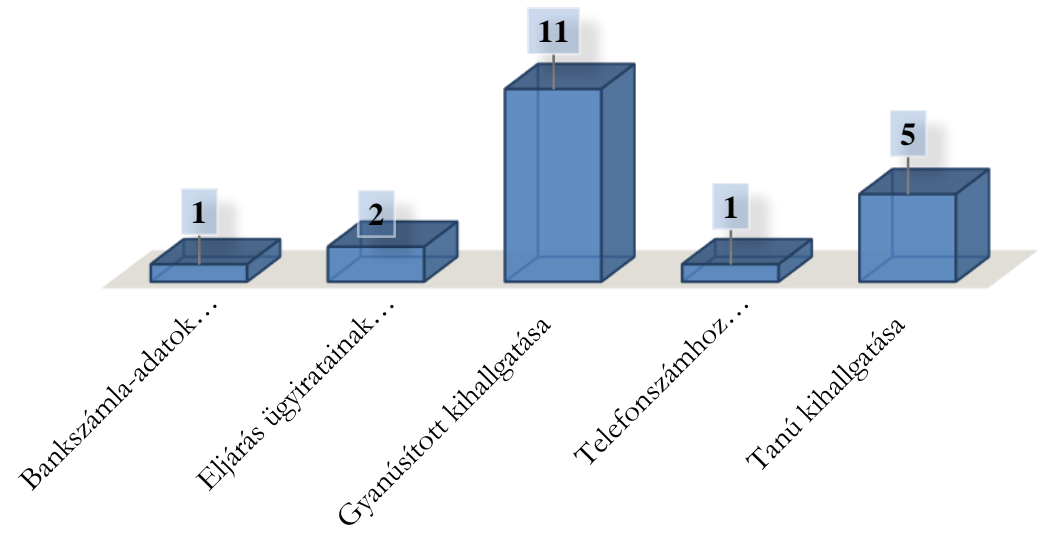

7. sz. ábra. Forrás: saját szerkesztés.

Az előbb felsorolt eljárási cselekmények közül a gyanúsított kihallgatása jelent meg a legnagyobb számban, aminek különösen fontos szerepe van a büntetőeljárásban. Ez az eljárási cselekmény vezet át a 
nyomozás felderítési szakaszából a vizsgálati szakaszába, amelyben az ügyészség már irányítási jogkörrel rendelkezik, tehát az ügy ura és a nyomozás lezárását követôen nyílik lehetôség vádemelésre. ${ }^{26}$ Ezen túl a büntetőeljárás terheltje jogosult arra, hogy megismerje a gyanúsítás tárgyát, hiszen a terhelt eme aktus útján válik gyanúsítottá, és innentől kezdve gyakorolhatja eljárási jogait. ${ }^{27} \mathrm{Ez}$ szintén alátámasztja azt, hogy a büntetőeljárás csak kivételes esetekben folytatható a gyanúsítás közlése nélkül, méghozzá olyan esetekben, amikor a terhelt külföldön tartózkodik és a valamilyen oknál fogva nemzetközi együttműködés útján sem megoldható a Magyarországnak történő kiadatása vagy átadása (mert az európai vagy nemzetközi elfogatóparancs kibocsátásának feltételei nem állnak fenn, a megkeresett állam a kiadatást vagy átadást megtagadja, a kiadatási vagy átadási eljárás 12 hónapnál hosszabban elhúzódik vagy a végrehajtó állam a keresett személy átadásának vagy kiadatásának halasztását rendelte el). Ez önmagában nem indokolja az eljárás folytatását a terhelt távollétében. Az eljárás folytatásának további feltétele, hogy azt a bűncselekmény tárgyi súlya vagy megitélése indokolja és az, hogy a terhelt eljáráson vagy valamely eljárási cselekményen történő részvétele egyéb nemzetközi bűnügyi jogsegélykérelem segítségével, illetve telekommunikációs eszköz alkalmazása útján sem biztosítható. ${ }^{28}$ Azaz az ENYH útján elrendelt gyanúsítás és a gyanúsított kihallgatása részben a terhelt érdekeit szolgálja, mert úgy is biztosítja az eljárásban történő részvételt, hogy a terhelt ténylegesen nem jelenik meg az eljáró hatóság előtt, részben pedig biztosítja eljárás lefolytathatóságát anélkül, hogy az elkövetőt távollévő terheltté kellene nyilvánítani.

A többi eljárási cselekményhez már nem társul ilyen önálló és az eljárás folytatására ilyen nagy befolyással bíró eljárási cél, hanem összefoglalóan azt lehet mondani, hogy a bizonyítékgyüjtést szolgálják. Hozzá kell tenni azonban ehhez, hogy az audiovizuális eszközök segítségével történő meghallgatás (mind a tanú, mind a gyanúsított esetében) jelentôs hozzáadott értékkel bír, és a közvetlenség elvének érvényesüléséhez nagy mértékben hozzájárul. Olyannyira rugalmas eljárási cselekményről van szó, hogy a bírósági szakban, a tárgyaláson akár még szembesítésre is sor kerülhet a segítségével, amit a Bonyhádi Járásbíróság előtt lefolytatott ügy példáz.

\footnotetext{
26 2017. ÉVI XC. TÖRVÉNY 392. \(1) bekezdés

27 2017. ÉVI XC. TÖRVÉNY 39. \(1) bekezdés a) pont

28 2017. ÉVI XC. TÖRVÉNY 755. 』 (1)-(2) bekezdés
} 
Az ENYH további sajátossága, hogy lehetőséget biztosít a kibocsátó hatóság számára, hogy meghatározzon olyan alaki követelményeket és eljárásokat, amelyeket a végrehajtó hatóságnak érvényesíteni kell az elrendelt nyomozási cselekmény végrehajtása során. Az ilyen - összefoglaló jelleggel - formalitásoknak nevezhető szabályok a külföldön beszerzett bizonyíték felhasználhatóságát szolgálják, ugyanis a tagállamok büntetőeljárási joga eltérő, amiből az következik, hogy a bizonyítékgyújtés szabályai is eltérőek lesznek. Amennyiben nem állna fenn a lehetőség, hogy a kibocsátó hatóság saját országa büntetőeljárási jogának a bizonyítékgyújtésre vonatkozó legfőbb rendelkezéseinek érvényesülését biztosítsa és a végrehajtó hatóság a saját tagállami büntetőeljárási joga alapján hajtaná végre a kért eljárási cselekményeket, fennállna a lehetősége annak, hogy a büntetőeljárás alá vont személyek jogai sérülnének, ami az így beszerzett bizonyíték kirekesztésével járhat. ${ }^{29}$ A vizsgált ügyekben előforduló eljárási cselekmények esetében a kibocsátó hatóság ilyen formalitásokat kizárólag a gyanúsítás és a tanú kihallgatása kapcsán kötött ki. A többi eljárási cselekmény esetén nem volt indokolt ezen formalitások érvényesítése. Megjegyzendő továbbá, hogy az audiovizuális eszközök segítségével történő meghallgatás esetén a kihallgatást eleve a kibocsátó hatóság foganatosítja, így a tolmács biztosításán túl ilyen esetben nem kell külön meghatározni azokat az alaki követelményeket és eljárásokat, melyeket tiszteletben kell tartani a cselekmény végrehajtása során, mert eleve a kibocsátó hatóság jogrendje vezérli a végrehajtást és a végrehajtó hatóság csak technikai segítséget nyújt a cselekmény lebonyolításában. ${ }^{30}$

Az esetek egyszerű megítélésére lehet következtetni abból, hogy a kibocsátó hatóság a vizsgált európai nyomozási határozatok közül 35 esetben csupán egyetlen nyomozási cselekmény elvégzését rendelte el, és a további hat ENYH-ban is csak kettő nyomozási cselekményt rendeltek el. Ezek között is megfigyelhető volt, hogy általában a terhelt személyes adatainak megismerése volt a cél (pl. bankszámlához vagy telefonszámhoz kapcsolódó személyes adatok megismerése), amelyet az így beazonosított gyanúsított kihallgatása követett. Másképp fogalmazva a vizsgált büntetőeljárások nem rendelkeztek számottevő nemzetközi elemmel, ami az ENYH alkalmazását indokolta egyéb, a tagállamok bünügyi együttmúködését szolgáló komplex jogintézmények helyett.

29 2017. ÉVI XC. TÖRVÉNY 167. \(5) bekezdés

30 2014/41/EU 24. cikk (3)-(5) bekezdés 
Szintén fontos információ, hogy az ENYH-t végrehajtották-e a végrehajtó tagállamban. Kiemelendő, hogy a vizsgált ügyek egyikében sem tagadta meg a végrehajtó hatóság a végrehajtást, ám több esetben sem lehetett foganatosítani az ENYH-ban elrendelt nyomozási cselekményt. Hét esetben azért nem járt sikerrel az ENYH, mert a tettes a legutolsó ismert lakcíméről ismeretlen helyre távozott és a felkutatására tett intézkedések nem vezettek eredményre. További három esetben a német büntetőeljárási kódex szabályai miatt nem lehetett végrehajtani az ENYH-t. Mindhárom büntetőeljárás járművezetés ittas állapotban bűncselekménye miatt indult, és mindhárom ENYH célja a gyanúsított kihallgatása volt. A német hatóságok szabály szerint idézték a terheltet, azonban a terheltek nem jelentek meg az idézésre és a német büntetőeljárási jog nem biztosít lehetôség a terhelt elóállítására ilyen csekély tárgyi súlyú bűncselekmény esetén. Végül egy esetben a megkeresett magyar hatóság nem tudta végrehajtani az ENYH-t, mivel a telefonszámhoz tartozó számlaadatokat a magyar szolgáltatók is csak egy évig kötelesek megőrizni és már nem lehetett az adatgyüjtést végrehajtani. Összességében tehát a 41 büntetőeljárásból 11 esetben nem hajtották végre az ENYH-t, mivel különböző okokból nem tudták foganatosítani a kért eljárási cselekményt és két esetben a magyar ügyészség elutasította a nyomozó hatóság kezdeményezését.

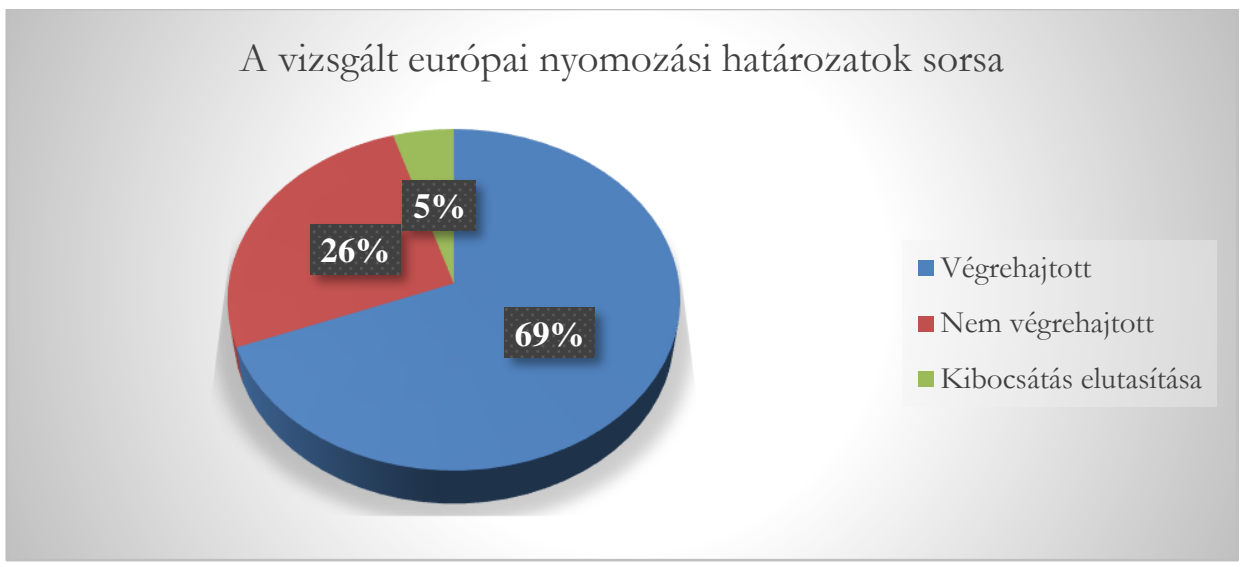

8. sz. ábra. Forrás: saját szerkesztés.

Végül, de nem utolsó sorban érdemes kitérni arra a kérdésre, hogy az ENYH útján beszerzett bizonyítékok felhasználhatók voltak-e a büntetőeljárásban. Ez az adat nem vizsgálható a külföldről érkező ENYH-k 
vonatkozásában, mivel az ügy további sorsáról nem tájékoztatják a végrehajtó hatóságot. Érdemes visszautalni arra, hogy egyáltalán miért merülhet fel kérdésként, hogy az ENYH útján külföldön beszerzett bizonyíték felhasználható-e: a válasz a tagállamok eltérő büntető igazságügyi rendszereiben keresendő. A büntetőeljárási kódexek változatos és egymástól különböző garanciákat biztosítanak a bizonyitékgyüjtés során is és vannak olyan garanciák, amik egy tagállamban biztosítottak, míg egy másik tagállamban nem. Amennyiben nincs olyan szabály, amelynek segítségével érvényesíthetôk e garanciák, a beszerzett bizonyíték nem volna felhasználható a bírósági szakban, hiszen a terhelt eljárási jogait sértő módon szerezték volna be azt. E célból figyelemre méltó, hogy a magyar hatóságok igen részletes alaki követelményeket határoztak meg minden ENYH-ban, amelyben a gyanúsított vagy tanú kihallgatását rendelték el. Ennél fogva a sikeresen végrehajtott ENYH-k útján beszerzett bizonyítékokat egyetlen, a magyar hatóságok előtt lefolytatott büntetőeljárásban sem rekesztette ki a bíróság a terhelt indítványára. Ugyanakkor az is megjegyzendő, hogy a 23-ból csupán 3 ügy zárult bírósági ítélettel, és 4 ügyben büntetôvégzést hozott a bíróság. Az ügyészség további 9 ügyet megszüntetett és 7 ügyben megrovást, illetve feltételes ügyészi felfüggesztést alkalmazott. Ez azt jelenti, hogy szigorú értelemben véve csupán a három bírósági szakig eljutó büntetőeljárásban vizsgálhatta volna a bíróság a bizonyítékok felhasználhatóságát és akkor sem hivatalból, hanem a felek kérelmére, ám erre nem került sor. Az ügyészség véleményem szerint a többi ügyben is felhasználta az ügy érdemében történő döntés meghozatala során az ENYH útján beszerzett bizonyitékot (feltéve, hogy végrehajtották azt, amelyre a 23-ból 15 esetben került sor). Viszont egyetlen ügy esetében sem mondható el, hogy az ügy érdemében hozott döntés indokolásában a határozatot meghozó hatóság kifejezetten utalt volna az ENYH útján beszerzett bizonyítékra, ami nem azt jelenti, hogy az így beszerzett bizonyíték nem került felhasználásra, ám azt is mutatja, hogy az ilyen bizonyíték inkább egyenrangú az ügyben beszerzett többi bizonyítékkal, minthogy kitüntetett helye lenne a büntetőeljárásban csak azért, mert a büntetőeljárás nemzetközi elemmel is rendelkezett. 


\section{KONKLÚZIÓ}

A dél-dunántúli gyakorlatelemzés eredményeiből két fontos következtetés is levonható. Egyrészről kijelenthető, hogy a gyakorlat alapján megfelelően müködik a forum regit actum elv, ami egy vezérlőelv, ami a külföldön beszerzett bizonyítékok nemzeti büntetőeljárásokban történő felhasználhatóságát szolgálja. Az elv a locus regit actum kiegészítőelve. A nemzetközi bủnügyi együttmûködésben eredetileg az utóbbi elv érvényesült, miszerint a megkeresett tagállam a jogsegély teljesítése során kizárólag saját jogrendszerének szabályai szerint járt el. Ám a már korábban is említett eltérő eljárási garanciák magukban hordozták annak a veszélyét, hogy ezzel a büntetőeljárás alá vont személyek, főképp a terhelt jogai sérülnek. A megoldást a forum regit actum elve nyújtja, amely alapján a jogsegélyért folyamodó állam meghatározhat bizonyos eljárási garanciákat, melyeket tiszteletben tart a megkeresett tagállam a jogsegély végrehajtása során, ezzel biztosítva a külföldön beszerzett bizonyíték felhasználhatóságát. ${ }^{31}$ Ezt az elvet örökíti tovább az ENYH-irányelv is. ${ }^{32}$ Vannak szerzők, akik súlyos kritikával illetik ezt a megoldást, mivel a bizonyitékgyújtés szabályainak harmonizálása nagyobb védelmet biztosítana a terhelt eljárási jogai számára. ${ }^{33}$ Viszont jelenleg ilyen minimumszabályok kialakításának a politikai realitása még az Európai Unióban sem áll fenn (korábban is említett okokból, miszerint a tagállamok fokozottan védelmezik büntetőjogukat az uniós behatástól).

Éppen ezért a fennálló gyakorlat elemzésével juthatunk csak közelebb annak a kérdésnek az eldöntéséhez, hogy a külföldön beszerzett bizonyítékok felhasználhatóságának garantálására melyik megoldás alkalmasabb: a forum regit actum elv vagy a bizonyítékgyújtés minimumszabályainak lefektetése? Alapjogi szempontból kevés lehetőség van az elv vizsgálatára a magyar gyakorlatban, ám az Európai Unió Bírósága előtt jelenleg is folyamatban van a Gavanozov II ügy. Az előzetes döntéshozatali eljárás alapjául szolgáló bolgár büntetőeljárás igazolni látszik az ENYH-val és a forum regit actum elvvel kapcsolatos előzetes alapjogi aggályokat, ugyanis hiába garantálja az irányelv az ENYH kibocsátásával szembeni jogorvoslatot, a bolgár büntetőeljárás egyes nyomozási cselekmények esetén kizárja ezt a lehetôséget. Az ügyben most az EUB

\footnotetext{
31 TÖRŐ, 2014. 130.o.

32 KUSAK, 2019. 6. Conclusions

33 KARSAI, 2012. 27.o.
} 
feladata, hogy az előzetes döntéshozatalra utalt kérdésről döntsön, miszerint a bolgár jog releváns szabályai alapjogsértők-e. ${ }^{34}$ Az ügyben hozott ítélet megmutatja majd, hogy az ENYH jelenlegi szabályai kellő védelmet biztosítanak-e a büntetőeljárás során az alapjogoknak. Ugyanakkor az elv hatékonyságát már sokkal jobban szemlélteti a magyar gyakorlat. Az esetjogi kutatás megmutatta, hogy az ENYH útján beszerzett bizonyítékok egytőlegyig felhasználhatók a hazai büntetőeljárásokban.

Emellett a kutatás eredményeiből levonható másik következtetés az ENYH kibocsátásának tipikus eseteire vonatkozik. A vizsgált ügyek egyikében sem szabtak ki végrehajtandó szabadságvesztést, amiből arra lehet következtetni, hogy az európai nyomozási határozatot enyhébb tárgyi súlyú ügyekben alkalmazzák. Ezen túl a vizsgált büntetőeljárások mindegyike relatíve egyszerű megítélésű volt, amit alátámaszt a büntetőeljárások átlagos hossza (2 év) és az, hogy viszonylag kis számú nyomozási cselekményt kellett foganatosítani a tényállás tisztázása érdekében. Sơt, a vizsgált ügyekrôl az is megállapítható, hogy nem valódi transznacionális bűncselekményekről van szó, hanem pusztán egy vagy legfeljebb néhány nemzetközi elemmel rendelkezőkről, amelyek a hagyományos transznacionális bűnözéssel ellentétben nagyrészt az ország határain belül maradnak. Ezt támasztja alá az, hogy a vizsgált esetek egyikében sem jelentkeztek a transznacionális bűnözés klasszikus formái: a bűncselekményeket nem több tagállam területén követték el és előkészületi cselekményekről érdemben nem is beszélhetünk, így a határon átnyúló bűncselekmény azon esete sem jelenik meg, amikor ezeket egy másik tagállamban valósítják meg. Szintén nem jelentek meg a vizsgált esetekben bűnszervezetek, melyek múködési területe az elkövetés tagállamától eltérő volna, és hasonlóképpen kizárhatók azok az esetek is, amikor egy bűncselekmény azért transznacionális, mert egy másik tagállam társadalmi, gazdasági vagy alkotmányos rendjét is veszélyezteti. ${ }^{35}$

Vagyis kijelenthető, hogy az európai nyomozási határozat fő alkalmazási területe nem a transznacionális bűncselekmény, ám kibocsátására mégis csak akkor van lehetőség, ha a büntetőeljárást lefolytató hatóságok más tagállam hatóságának eljárási segítségére szorulnak. Éppen ezért azt lehet mondani, hogy azon büntetőügyek túlnyomó többsége, amelyekben alkalmazandó az ENYH, csupán eljárási értelemben

${ }^{34}$ C-852/19 SZ. ÜGY

35 2012. ÉVI CLXXX. TÖRVÉNY 70/B. \(2) bekezdés 
nemzetközi, mert a transznacionális bűnözés klasszikus kritériumai nem jelentkeznek. Még a vizsgált ügyek között bonyolultabbnak ítélhető gazdasági és vagyon elleni bűncselekmények esetén sem jelenik meg a bűncselekmény több tagállamra kiterjedő mivolta. A Bonyhádi Járásbíróságon lefolytatott ügyben például a terhelt sikkasztást követett el azzal, hogy üzletkötőként a rábízott repcepogácsát értékesítette ugyan, ám sajátjaként és a befolyt vételárat nem bocsátotta a sértettek rendelkezésére. A bűnügy nemzetközi vonatkozása az volt, hogy a sértettek más tagállamban éltek és az ENYH kibocsátása egyrészről a sértettek meghallgatását szolgálta, másrészt annak tisztázását, hogy az elkövetési tárgy valóban a sértettek tulajdonát képezte. Ezzel szembeállítható például a parndorfi ügy, amely kétséget kizáróan transznacionális, határon átnyúló bűncselekmény, amelyet három ország területén (Magyarországon, Ausztriában és Németországban) követtek el. Az ügyben egy jól szervezett bűnszervezet embercsempészést követett el, melynek keretében a magyar határról egészen Németországig szállítottak migránsokat. Kézenfekvő megoldás lett volna egy közös nyomozócsoport létrehozása, ám a német hatóságok még nem derítették fel teljesen a bűncselekményeket, ezért nem voltak adottak a létrehozás feltételei. Az ügy bonyolultságát mutatja, hogy a közös nyomozócsoport hiányában több tucat nemzetközi jogsegélykérelmet kellett kibocsátania a magyar hatóságnak a külföldön fellelhető bizonyítékok beszerzése miatt. ${ }^{36}$ Ezzel ismét szembeállíthatók a kutatásba bevont ügyek, amelyekben csak elvétve fordult elő, hogy több ENYH-t kelljen kibocsátani.

Az ENYH-t érdemes összevetni még az EU tagállamai között megvalósuló bűnügyi együttműködés másik zászlóshajójával, az európai elfogatóparancs jogintézményével is. A vizsgált ügyek közül csupán egyben fordult elő, hogy egy ENYH és az EEP versengett egymással. Az ügyben a terhelt az esti órákban a horvát-magyar határszakasz horvát oldalához kísért hét fő schengeni vízummal nem rendelkező török állampolgárt. Ezt követően átvágta a határkerítést és az így nyitott résen átkísérte Magyarország területére a török állampolgárokat. Ezután a személyeket egy lakókocsihoz kísérte azzal, hogy másnap autóval felveszik őket. Mindezt személyenként 100 euróért vállalta.

Mivel a terhelt Romániába távozott, ezért a büntetőeljárás folytatása céljából a magyar hatóság európai elfogatóparancsot bocsátott ki, hogy biztosítsa a terhelt jelenlétét a büntetőeljárás során. A román társhatóságok

36 Szijártó, 2020. 439-445.o. 
jelezték, hogy a terhelt éppen büntetését tölti egy romániai büntetésvégrehajtási intézetben, ám azzal a feltétellel átadták volna az elkövetôt, hogy a kiszabott büntetést Romániában hajtják végre, ám végül az elfogatóparancsot visszavonták és helyette ENYH útján közölték a terhelttel a gyanúsítást, illetve foganatosították a gyanúsított kihallgatását. A két jogintézménynek különböző előnyei vannak. Lényegében az EEP képes garantálni a terhelt jelenlétét a büntetőeljárás során, ha csak ideiglenes is, ám ezzel szemben az ENYH gyorsabb megoldást garantál azzal, ha a végrehajtó hatóság végzi a gyanúsítást és a kihallgatást. Mivel a videókonferencia útján való meghallgatás nem biztosított (ugyanis a terhelt beleegyezéséhez kötött), ezért a közvetlenség elvét az EEP jobban szolgálja. Ugyanakkor az, hogy melyik jogintézményhez érdemes folyamodni, minden egyes ügyben egyedi értékelést igényel, hiszen az EEP végrehajtása költségesebb és időigényesebb. Amennyiben az ügy tárgyi súlya nem indokolja, elegendőnek bizonyulhat az ENYH kibocsátása, amely szintén garantálja a közvetlenség elvét, csupán kisebb mértékben, mint az EEP. Ezt támasztják alá a vizsgált ügyek is, amelyek nagy részében az ENYH célja pont a terhelt távollétében lefolytatott eljárás elkerülése volt.

\section{FELHASZNÁLT IRODALOM}

ARMADA, INES (2015). The European Investigation Order and the Lack of European Standards for Gathering Evidence. New Journal of European Criminal Law, 7(1), 8-31. DOI azonosító: https://doi.org/10.1177/203228441500600103

FARKAS ÁKOS (2011). Az Európai Bíróság és a kölcsönös elismerés elvének hatása az európai büntetőjog fejlődésére, Miskolci Jogi Sz̨emle, különszám, 62-77. letöltés helye: https://www.mjsz.unimiskolc.hu/files/egyeb/misz/201102/7 farkasakos.pdf (letöltve: 2021.09.20.)

FARKAS Krisztina, KÁRMÁN GABriella (2020). Nemzetközi együttmúködés a bizonyítékok beszerzésében - empirikus megközelítésben. In: Vókó, György (szerk.). Kriminológiai Tanulmányok 57. kötet. Budapest: Országos Kriminológiai Intézet

LABAYLE, HENRI (2016). The institutional framework. In Valsamis Mitsilegas, Maria Bergström, Theodore Konstadinides (szerk.). Research Handbook on EU Criminal Law. Cheltenham: Edward Elgar Publishing 
KARSAI, KRISZTINA (2012). Emberi jogok védelme és az európai nyomozási határozat. Rendészet és emberi jogok, 2(3), 23-34.

KlimeK, Libor (2017). Mutual Recognition of Judicial Decisions in European Criminal Law. Cham: Springer

KusAK, MARTYNA (2019.) Mutual admissibility of evidence and the European investigation order: aspirations lost in reality. Letöltés helye: https://link.springer.com/article/10.1007/s12027-018-0537-0 (Letöltve: 2021.09.31.)

Mirisan, Ligia-VALENTiNA (2018). The European Investigation Order. Annales Universitatis Apulensis Series Jurisprudentia, 21(1), 217-232.

MitsiLegas, VAlsamis (2016). EU Criminal Law after Lisbon. London: Hart

Montero, Regina Garcimartín (2017). The European Investigation Order and the Respect for Fundamental Rights in Criminal Investigations. eucrim 12(1), letöltés helye: https://eucrim.eu/articles/european-investigation-order-respectfundamental-rights/ (letöltve: 2021.08.10.) DOI azonosító: 45-50. https://doi.org/10.30709/eucrim-2017-006

RAMOS, Jorge A. EsPinA (2019). The European Investigation Order and Its Relationship with Other Judicial Cooperation Instruments. eucrim, 14(1), letöltés helye: https://eucrim.eu/articles/european-investigationorder-and-its-relationship-other-judicial-cooperation-instruments/

(letöltve: 2021.09.21.) DOI azonosító: https://doi.org/10.30709/eucrim-2019-004

SZIJÁRTÓ ISTVÁN (2020). A közös nyomozócsoportok európai jogintézménye hatékonyságában kulcsa: az Europol és az Eurojust szerepe a közös nyomozócsoportokban. In: Mailáth György Tudományos Pályázat 2019: Díjazott dolgozatok. Budapest: Országos Bírósági Hivatal

SZIJÁRTÓ ISTVÁN (2020). Az európai büntetőjog területi hatálya: az opt-out és a vészfékmechanizmus hatása az Európai Unió tagállamai büntető igazságügyi együttműködésére. Scriptura, 7(2), 70-83. letöltés helye: https://onszak.pte.hu/userfiles/lapszam/16/scriptura20ii teljes.pdf (letöltve: 2021.09.10.)

TÖRŐ ANDREA (2014). Bizonyíték-transzfer az európai bűnügyi együttmúködésben - különös tekintettel az európai nyomozási határozatra. Szeged: Szegedi Tudományegyetem 
Valsamis Mitsilegas, Jörg Monar, Wyn Rees (2003). The European Union and Internal Security. Guardian of the People? Hampshire: Palgrave Mcmillan

\section{Felhasznált források}

17/2014. (XII. 23.) OBH UTASÍTÁS

2012. ÉVI CLXXX. TÖRVÉNY AZ EURÓPAI UNIÓ TAGÁLlAMAIVAL FOLYTATOTT BÜNÜGYI EGYÜTTMŰKÖDÉSRŐL 2017. ÉVI XC. TÖRVÉNY A BÜNTETŐELJÁRÁSRÓL

A TANÁCS 2002. JÚNIUS 13-I 2002/584/IB KERETHATÁROZATA AZ EURÓPAI ELFOGATÓPARANCSRÓL ÉS A TAGÁLLAMOK KÖZÖTTI ÁTADÁSI ELJÁRÁSOKRÓL

A TANÁCs És AZ Európai PARLAMENT 2014. ÁPRILIS 3-I 2014/41/EU IRÁNYELVE A BÜNTETŐÜGYEKBEN KIBOCSÁTOTT EURÓPAI NYOMOZÁSI HATÁROZATRÓL

A TANÁCS ÉS AZ EURÓPAi PARLAMENT 2018. NOVEMBER 14-I 2018/1805/EU RENDELETE A BEFAGYASZTÁST ÉS AZ ELKOBZÁST ELRENDELŐ HATÁROZATOK KÖLCSÖNÖS ELISMERÉSÉRŐL

AZ EURÓPAI IgAZSÁGÜGYI HÁLÓZAT IgAZSÁGÜGYI KÖNYVTÁRA. letöltés helye:

https://www.ejn-

crimjust.europa.eu/ejn/EJN Library StatusOfImpByCat.aspx?l=HU\&C ategoryId=120 (letöltve: 2021.09.10.)

EuROJusT (2020). Report on Eurojust's casework in the field of the European Investigation Order, letöltés helye: https://www.eurojust.europa.eu/sites/default/files/2020-11/2020-

11 EIO-Casework-Report CORR .pdf (letöltve: 2021.09.20.)

C-852/19 sz. ügy Ivan Gavanozov elleni büntetőeljárás [ECLI:EU:C:2021:346]

MAASTRICHTI SZERZŐDÉS 1992.

STOCKHOLMI PROGRAM (2010/C 115/01)

ZÖLD KÖNYV A BÜNTETŐÜGYEKBEN FELVETT BIZONYÍTÉKOKNAK A TAGÁLLAMOK ÁLTAL MÁSIK TAGÁLLAMTÓL TÖRTÉNŐ MEGSZERZÉSÉRŐL ÉS ELFOGADHATÓSÁGUK BIZTOSÍTÁSÁRÓL (COM(2009)0624) 